\title{
BONCUK NAZAR
}

\section{RODRÍGUEZ MARCO NA ${ }^{1}$, SOLANAS ÁLAVA S ${ }^{2}$}

La fuerza del mal de ojos (nazar) es un elemento extensamente aceptado y temido en Turquía. Es la explicación para la enfermedad y penalidades a las que no se encuentra origen y esa es la razón por la que cada madre turca fija un pequeño amuleto en forma de ojo azul en las ropas de su hijo. Según la tradición la mejor manera de asegurarse que un niño ha sido víctima del mal de ojo es midiendo sus dos piernas. Si una de ellas es significativamente más larga que la otra es indudable que el mal está aparente...

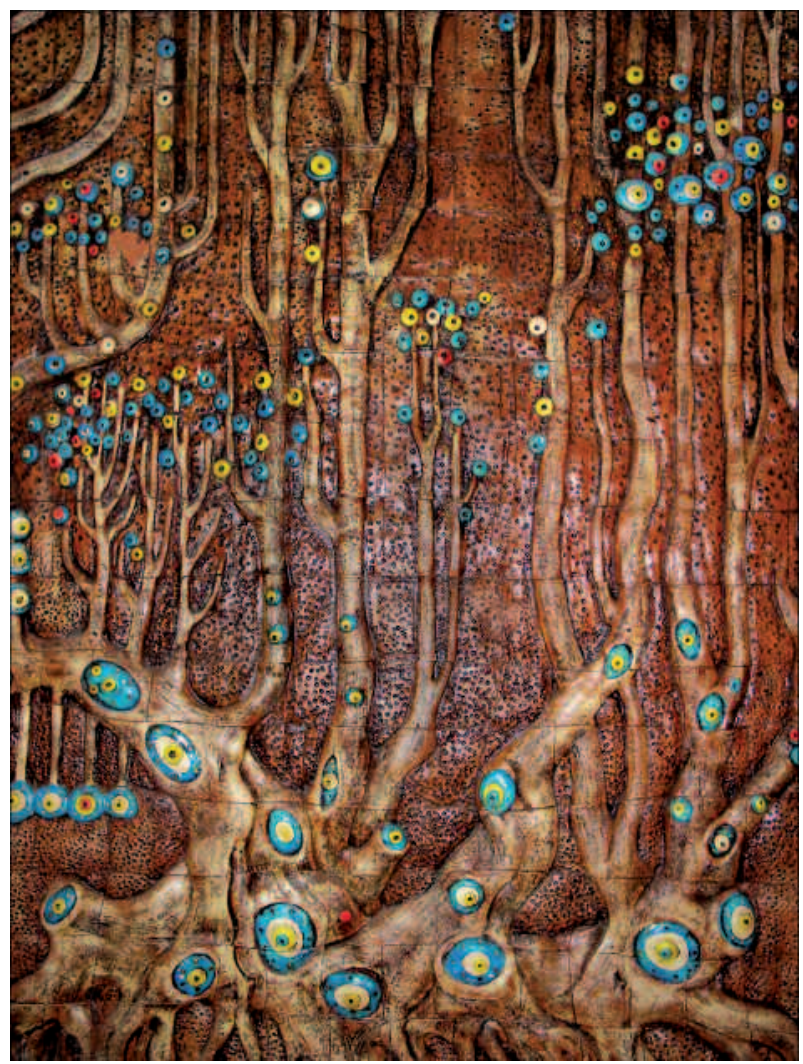

Fig. 1: Árbol del Boncuk Nazar. Adorno de la fachada en una casa particular de Estambul.
El Boncuk Nazar es un amuleto azul, color típico para la protección de su portador y asemeja un ojo que protege contra el mal de ojo o la envidia ajena. La creencia es que consciente o inconscientemente, en los elogios siempre está incluida la envidia y el resentimiento. Se puede encontrar en toda Turquía usado por las gentes de allí en pulseras, pendientes o collares, en la casa, en la oficina o en el coche y a los bebés se les incluye en el ajuar con el fin de protegerlos. En el hogar, se debe colocar a la entrada, así cualquier visitante lo verá y se estará protegido y toda negatividad y malas vibraciones serán dirigidos al mismo (figs. 1-3).

El origen del ojo azul se debe a la invasión de los pueblos del norte. Los nórdicos tenían los ojos azules y los pueblos de Anatolia pensaron que ellos les echaban mal de ojo por lo que para contrarrestarlo crearon el ojo azul.

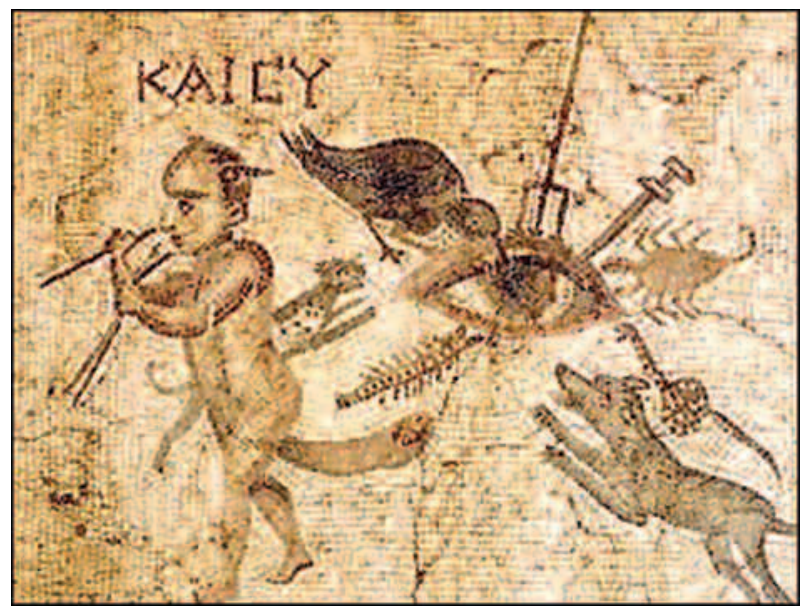

Fig. 2: Mosaico del Imperio Romano en el museo de Antakya, Turquía. Se aprecia un pájaro que picotea un ojo maligno, un perro que le ladra, un tridente clavado en él y un demonio sonriente y despreocupado que camina hacia delante.

Servicio de Oftalmología. Hospital de Navarra.

1 Licenciado en Medicina. Servicio de Oftalmología. Hospital de Navarra.

E-mail: Nelson5000@1atinmail.com

2 Licenciada en Medicina. Osatek. Vitoria. España. 


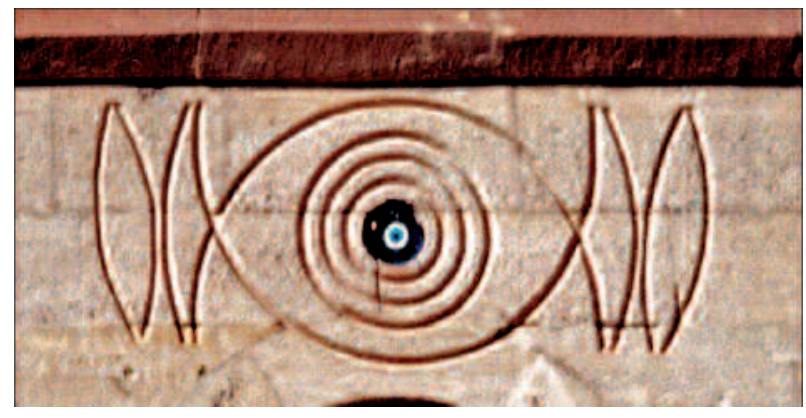

Fig. 3: Detalle en la parte superior de la puerta en una casa de Capadocia, con el Boncuk Nazar presidiendo la misma.
Se producen en los pequeños pueblos del oeste de Turquía en hornos primitivos donde utilizan el cobalto, el ópalo o el zinc para proporcionar el color azul, y para obtener un buen resultado utilizan la leña de pino.

\section{BIBLIOGRAFÍA}

- http://www.aturquia.com/tradiciones/tradiciones.htm

- Raquel Jiménez. Estambul, Capadocia y el Mediterráneo. Segunda Edición; España: Anaya S.A.; 2007.

- Stephane Yerasimos. Constantinopla: la herencia histórica de Estambul. Köln: Ullman \& Köneman; 2007. 